\title{
Expression profile of mucins (MUC2, MUC5AC and MUC6) in Helicobacter pylori infected pre-neoplastic and neoplastic human gastric epithelium
}

\author{
Subramani Durai Babu ${ }^{1}$, Venkataraman Jayanthi², Niranjali Devaraj ${ }^{3}$, \\ Celso A Reis ${ }^{4}$ and Halagowder Devaraj*1
}

Address: ${ }^{1}$ Unit of Biochemistry, Department of Zoology, University of Madras, Guindy, Chennai, India, ${ }^{2}$ Department of Gastroenerology, Stanley Medical College and Hospital, Chennai, India, ${ }^{3}$ Department of Biochemistry, University of Madras, Guindy Campus, Chennai, India and ${ }^{4}$ IPATIMUP - Institute of Molecular Pathology and Immunology of the University of Porto, Portugal

Email: Subramani Durai Babu - durai_reddy@yahoo.co.in; Venkataraman Jayanthi - drjayant1@vsnl.com; Niranjali Devaraj - nirangali@yahoo.com; Celso A Reis - celso.reis@ipatimup.pt; Halagowder Devaraj* - hdrajum@yahoo.com

* Corresponding author

Published: 19 March 2006

Molecular Cancer 2006, 5:10 doi:10.1186/1476-4598-5-10
Received: 07 February 2005

Accepted: 19 March 2006

This article is available from: http://www.molecular-cancer.com/content/5/1//0

(C) 2006 Babu et al; licensee BioMed Central Ltd.

This is an Open Access article distributed under the terms of the Creative Commons Attribution License (http://creativecommons.org/licenses/by/2.0), which permits unrestricted use, distribution, and reproduction in any medium, provided the original work is properly cited.

\begin{abstract}
Background: Helicobacter pylori (H. pylori) causes gastritis and intestinal metaplasia (IM) that may evolve to gastric carcinoma. The objective of this study was to compare the profile of mucins in the progressive stages of $H$. pylori infected pre-neoplastic and neoplastic human gastric epithelium. We used a panel of monoclonal antibodies with well-defined specificities of MUC2, MUC5AC and MUC6 to characterize the expression pattern of mucins by immunohistochemistry.

Methods: RUT and ELISA were down for $H$. pylori confirmation. Human gastric biopsy sections were stained using immunohistochemistry with MUC2, MUC5AC and MUC6 antibodies.

Results: MUC5AC was expressed in the superficial epithelium and the upper part of the gastric pits. MUC6 expression was detected in the lower part of the gastric glands. MUC2 was expressed in intestinal metaplasia, mostly in goblet cells. The mucin expression profile in the progressive stages of $H$. pylori infected human gastric epithelium allows the identification of intestinal metaplasia, which is characterized by a decreased expression of the gastric mucins (MUC5AC and MUC6) and de novo expression of MUC2.

Conclusion: In conclusion, our results suggest that there is altered expression of MUC5AC and MUC6 together with the aberrant expression of MUC2 in intestinal metaplasia, during the process of gastric carcinogenesis. The present study indicates that the MUC2 mucin expression pattern is a reliable marker of intestinal metaplasia, which appears in the context of $H$. pylori infected individuals.
\end{abstract}

\section{Background}

Helicobacter pylori colonizes human gastric mucosa and causes gastritis and intestinal metaplasia (IM), which may evolve towards gastric carcinoma [1-3]. H. pylori infection was established as a type I human carcinogen in IARC [4]; it was recently shown that the bacteria are also capable of inducing gastritis, IM, and gastric carcinoma in Mongolian gerbils [5-8]. In humans, $H$. pylori also colonizes the 

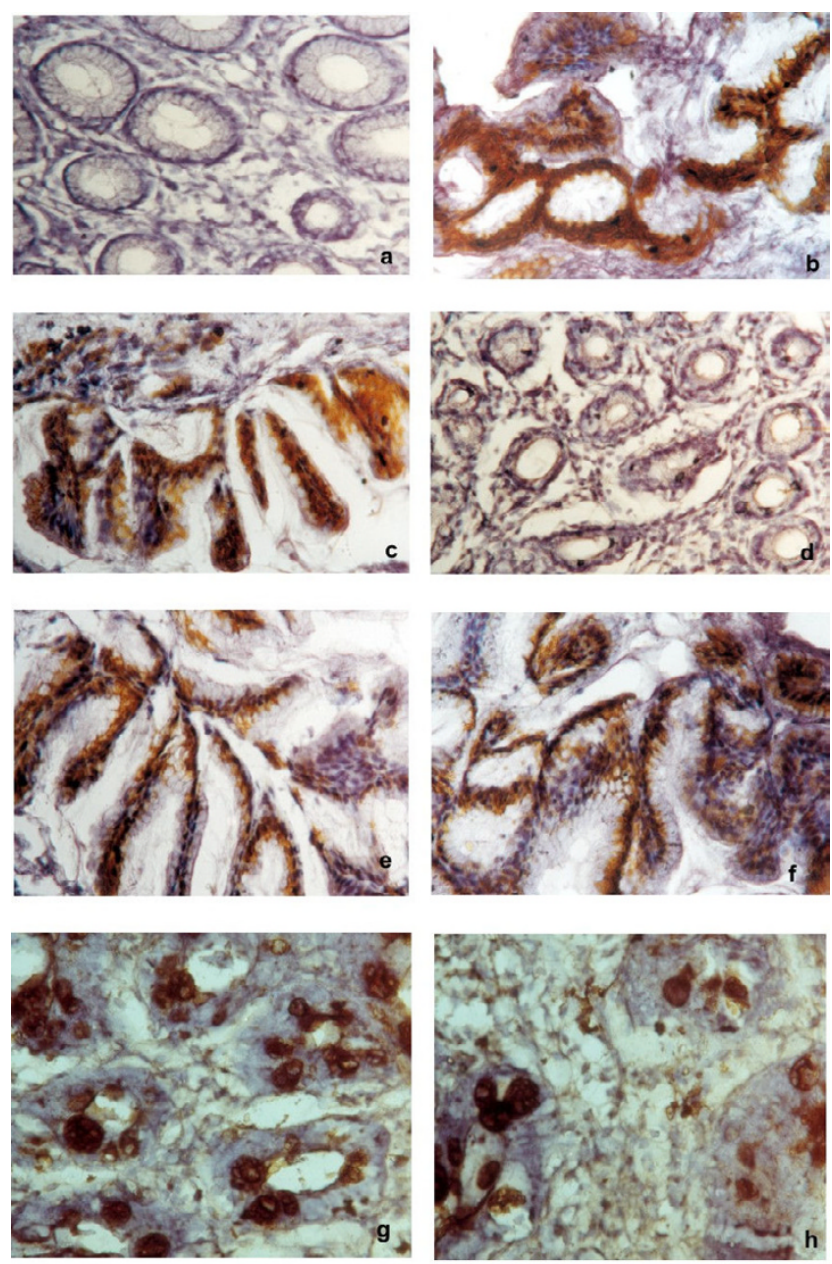

Figure I

Immunohistochemical staining of MUC2, MUC5AC and MUC6 mucins in $\mathrm{H}$. pylori infected patients. $a$. MUC2 staining of normal gastric mucosa (Original magnification $\times 100)$. b. MUC5AC staining of normal gastric mucosa (Original magnification $\times 100$ ). c. MUC6 staining of normal gastric mucosa (Original magnification $\times 100$ ). d. MUC2 staining of Atrophic gastritis (Original magnification $\times 100$ ). $\mathbf{e}$. MUC5AC staining of Atrophic gastritis (Original magnification $\times 100$ ). f. MUC6 staining of Atrophic gastritis (Original magnification $\times 100)$. g. MUC2 staining of Intestinal metaplasia (Original magnification $\times 100$ ). h. MUC5AC staining of Intestinal metaplasia (Original magnification $\times 100$ ).

duodenal mucosa whenever there is gastric metaplasia [9]. H. pylori infection in human is therefore dependent on the gastric microenvironment, which is determined to a large extent by the mucin and carbohydrate composition of the gastric mucin layer.

Mucins are heavily glycosylated glycoproteins that are the major components of the mucous viscous gel covering the surface epithelial tissues [10]. To date, nine distinct epi- thelial mucin genes (MUC1, 2, 3, 4, 5AC, 5B, 6, 7, and 8) have been identified [11-21]. In situ hybridization and immunohistochemical studies have shown that these mucins are differentially expressed in epithelia with cell type specificity [21-24]. The normal gastric mucosa shows cell types specific expression of MUC1, MUC5AC, and MUC6, with first two mucins found in the superficial epithelium and MUC6 in the deep glands $[22,25,26]$. MUC6 is mainly expressed in gastric mucosa. The normal gastric mucosa does not express MUC2 $[25,27]$.

Changes in the expression levels and glycosylation patterns of mucins have been associated with several diseases, including carcinomas [27-31]. In gastric cancer, alterations in mucin polypeptide have been reported: loss of expression of MUC5AC [23,26,32], increased mucin heterogenesity [23]. These observations suggest that mucin alterations can be regarded as "molecular" markers of malignant transformation of gastric mucosa. Further more, a recently published investigation strongly suggested MUC5AC as a putative $H$. pylari receptor $[33,34]$.

In this present study, we have characterized the pattern of mucins expression in the progressive stages of $H$. pylori infected human gastric carcinoma. We have used a comprehensive panel of monoclonal antibodies, with wellcharacterized specificities directed to MUC2, MUC5AC and MUC6 mucins.

\section{Results}

Expression pattern of MUC2, MUC5AC and MUC6 mucins in normal gastric mucosa

MUC5AC was highly expressed in foveolar epithelium and mucous neck cells of antrum (>75\%, Fig. 1b; Fig. 3b; Table 2). Expression of MUC6 was detected in the glands of the antrum ( $>75 \%$, Fig. 1c; Fig. 3c; Table 3 ) and MUC2 was not detected in normal gastric mucosa (Fig. 1a; Fig. 3a; Table 2).

\section{Immunodetection of mucins in atrophic gastritis}

There was expression of MUC5AC in all the cases of columnar cells (Fig. 1e; Fig. 3b; Table 2). The percentage of stained cells varied from case to case, in most cases, there was a trend for higher number of cells expressing MUC5AC ( $>75 \%)$ in the superficial part of the metaplastic glands than in deep part. MUC6 was detected in columnar cells (>50\%; Fig. 1f; Fig. 3c; Table 2) and MUC2 was not detected in atrophic gastritis (Fig. 1d).

\section{Immunodetection of mucins in intestinal metaplasia}

There was decreased level expression of MUC5AC and MUC6 in all the cases $(>50 \%)$, both in goblet and in columnar cells (Fig. 1h, Fig. 2a; Fig. 3b, Fig. 3c; Table 2). The percentage of stained cells varied from case to case, de novo expression of intestinal mucin MUC2 was observed 

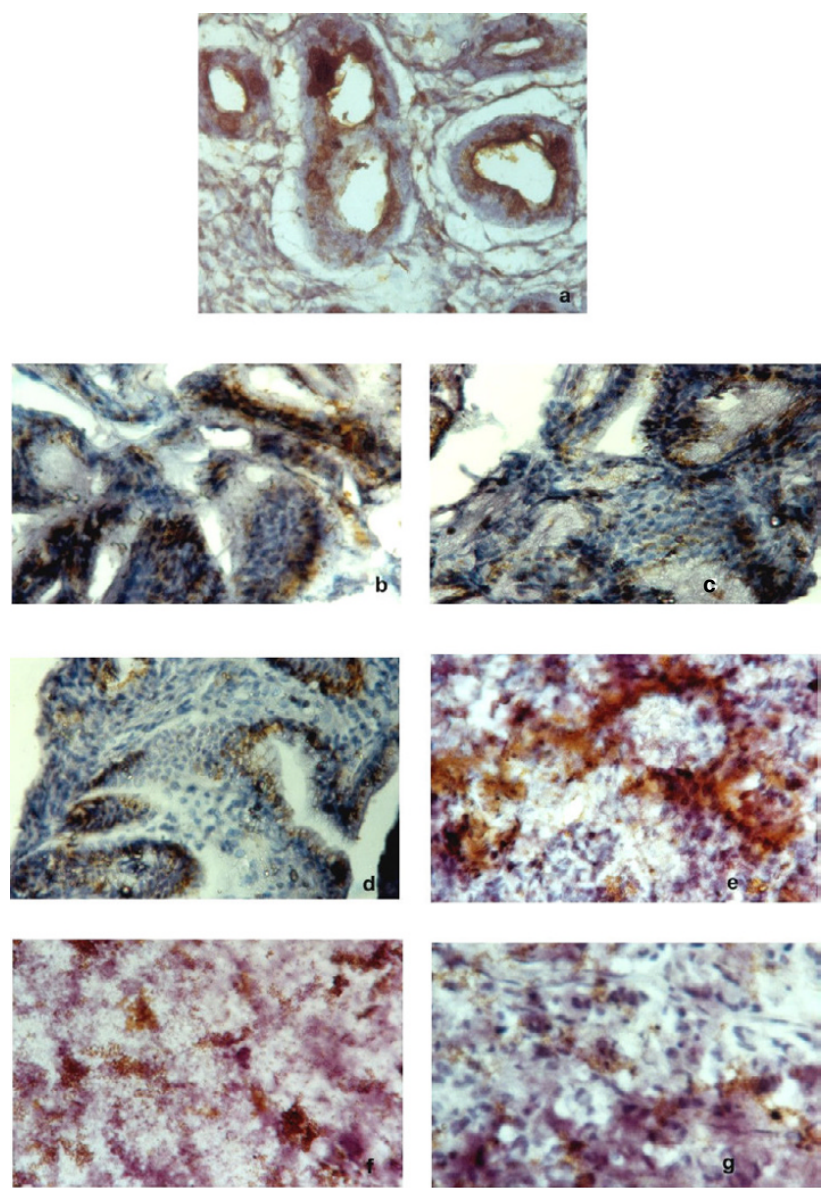

Figure 2

Immunohistochemical staining of MUC2, MUC5AC and MUC6 mucins in $H$. pylori infected patients. a. MUC6 staining of Intestinal metaplasia (Original magnification $\times 100)$. b. MUC2 staining of dysplasia (Original magnification $\times 100$ ). c. MUC5AC staining of dysplasia (Original magnification $\times 100$ ). d. MUC6 staining of dysplasia (Original magnification $\times 100)$. e. MUC2 staining of carcinoma (Original magnification $\times 100)$. f. MUC5AC staining of carcinoma (Original magnification $\times 100)$. g. MUC6 staining of carcinoma (Original magnification $\times 100$ ).

$(>75 \%)$, and its expression displayed a diffuse cytoplasmic pattern in goblet cells (Fig. 1g; Fig. 3a; Table 2).

\section{Immunodetection of mucins in dysplasia}

There was decreased level expression of MUC5AC and MUC6, than intestinal metaplasia (>50\%). MUC5AC and MUC6 displayed a diffuse cytoplasmic expression pattern in columnar cells (Fig. 2c; Fig. 2d; Fig. 3d; Fig. 3; Table 2). MUC2 expression displayed a diffuse cytoplasmic pattern in goblets cells (>50\%, Fig. 2b; Fig 3a; Table 2).

\section{Immunodetection of mucins in carcinoma}

MUC5AC and MUC6 expression were frequently observed in early carcinoma $(>50 \%)$ than advanced carcinomas $(>25 \%)$. In advanced carcinomas, we observed a trend for decreased immunoreactivity in deep areas than in the superficial areas. MUC5AC and MUC6 expressions were decreased in advanced carcinomas (>25\%; Fig. 3a; Fig. 3b; Fig. 3c; Fig. 2e, Fig. 2f, Fig. 2g; Table 2).

\section{Discussion}

In this present study, we have shown that the pattern of mucins expression in the progressive stages of $H$. pylori infected human gastric epithelium. Mucins are expressed with a cell- and tissue-specific pattern in normal tissue. Alterations of the expression pattern of mucins have been described in carcinomas as well as in their precursor lesions; in the latter, altered mucin carbohydrate and peptide moieties may constitute molecular markers of increased risk of malignant transformation $[27,35,36,38$ 40].

In agreement with previous studies reporting the distribution of mucins in normal stomach, we found MUC5AC is highly expressed in foveolar cells of antrum, as reported [26,27,32,37-39]. We also found that MUC6 is expressed in mucous cells of the neck zone in pyloric glands of the antrum with similar pattern to that described previously $[22,23,47]$. The expression of MUC2 was usually not detected in normal gastric mucosa as described in the previous reports $[25,27,40]$.

Intestinal metaplasia is one of the lesions identified in the cascade of event that precedes the development of gastric carcinoma [41]. Intestinal metaplasia comprises the replacement of the gastric mucosa by an epithelium that resembles histologically the intestinal mucosa. Altered mucin expression patterns have been observed in $H$. pylori infected intestinal metaplasia, including under expression of MUC5AC and MUC6 and de novo expression of MUC2 mostly in goblet cells $[30,48]$. These results support the assumption that the intestinal metaplasia does represent a differentiation of the mucosa toward a intestinal phenotype $[42,43]$.

The decreased expression of MUC5AC and MUC6 mucin in gastric carcinomas were confirmed in the present study. The expression of MUC5AC in early gastric carcinoma of the present series, regardless of the histological type of the tumors, contrasts with the decreased level expression of MUC5AC immunoreactivity in almost half of the advanced carcinomas which suggest that all gastric carcinomas retain at least some cells with a gastric phenotype during the first steps of neoplastic development (26). This assumption is further supported by the decreased immunoreactivity in deep areas compared with superficial areas 
$\mathbf{a}$

b

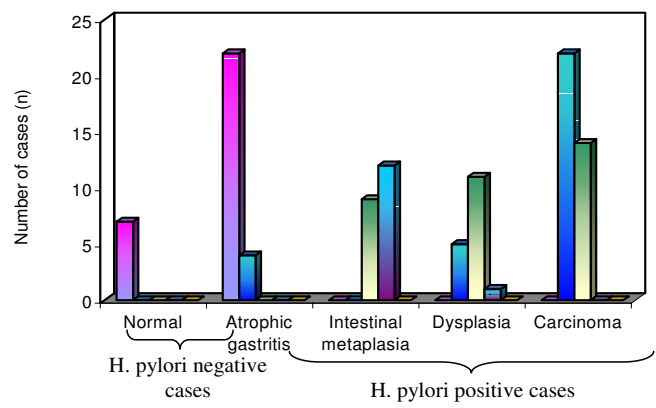

$\square(>5 \%)$ Negative $\quad \mathbf{\square}(5-25 \%)$ Few positive cells 口(25-50\%) Well-defined area $\quad$ 口(50-75\%) Extensive area stained $\square(75-100 \%)$ Most of the cells stained
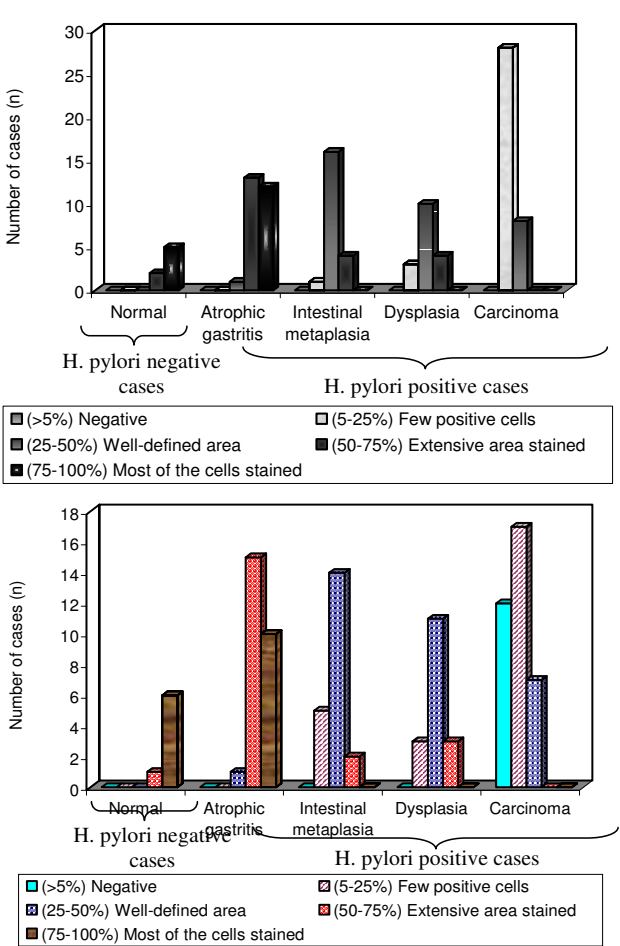

Figure 3

Expression pattern of mucins (MUC2, MUC5AC and MUC6) in $H$. pylori infected pre-neoplastic and neoplastic human gastric epithelium. a. MUC2 expression in $H$. pylori infected pre-neoplastic and neoplastic human gastric epithelium. b. MUC5AC expression in H. pylori infected pre-neoplastic and neoplastic human gastric epithelium. c. MUC6 expression in $H$. pylori infected pre-neoplastic and neoplastic human gastric epithelium.

of the advanced carcinomas. These results are in agreement with previous results showing that gastric cancer progression is accompanied by alteration of the expression of several mucin genes [14]. Finally, we observed that the intestinal mucin MUC2 is expressed in every intestinal metaplasia, which is a lesion that appears during the proc- ess of gastric carcinogenesis in the context of $H$. pylori infected

individuals.

\section{Conclusion}

Although $H$. pylori has been classified as a class I carcinogen by the IARC [4] the mechanism of gastric carcinogenesis remains poorly understood. In pre-neoplastic gastric mucosa, the expression of all the three mucin antigens did not appear to correlate with the severity of inflammation and $H$. pylori status. Results from the present study may suggest that $H$. pylori infection acts as an initiator of this carcinogenesis cascade by inducing inflammation and, in some cases, the subsequent metaplastic change. Intestinal metaplasia is accompanied by the induction of expression MUC2 and decreased expression of MUC5AC and MUC6. These alterations may favor the development of gastric carcinoma. The present study suggests that MUC2 is a marker of intestinal metaplasia and may be used for the early detection of this lesion in $H$. pylori infected pre-neoplastic human gastric epithelium.

\section{Materials and methods Tissue samples}

Fifty nine gastric biopsy specimens and $3 \mathrm{ml}$ of blood were obtained from Stanley Medical College and Hospital, Chennai. All biopsy tissue samples were collected after informed consent. This study was carried out after obtaining clearance from the ethical board of the hospital. All biopsy specimens were fixed in $10 \%$ buffered formalin and routinely embedded in paraffin wax. $4 \mu \mathrm{m}$ thin serial sections were cut and used for immunohistochemistry. $H$. pylori infection was confirmed by RUT and ELISA [43]. Hematoxylin and Eosin stained sections were used to classify gastritis graded according to revised Sydney classification [44], gastric tumors according to the classification of Lauren [45] and WHO classification [46]. We studied 7 cases of normal Human gastric epithelium (7 biopsies), 26 cases of Atrophic gastritis (26 biopsies), 21 cases of Intestinal metaplasia ( 21 biopsies), 17 cases of dysplasia (17 biopsies) and 36 cases of carcinoma in which 21 cases early carcinoma and 15 cases advanced carcinoma (16 biopsies and 20 surgical specimens).

\section{Monoclonal antibodies}

A panel of three monoclonal antibodies was used to determine the expression of mucins (MUC2, MUC5AC and MUC6). The specificities, references and dilutions of the antibodies are listed in Table 1.

\section{Immunohistochemistry}

Sections from normal, pre-neoplastic and neoplastic gastric tissues were immuno stained according to Reis et al [47] with slight modifications. Sections designed for neuraminidase treatment were washed twice in phosphate buffered saline (PBS), pH 7.4 and incubated with neu- 
Table I: Specificities, origins and dilutions of the monoclonal antibodies.

\begin{tabular}{lccc}
\hline Monoclonal antibody & Specificity & Reference & Dilution \\
\hline PMHI & MUC2 & Reis et al $[11]$ & Undiluted \\
CLH2 & MUC5AC & Reis et al $[12]$ & $1: 2$ \\
CLH5 & MUC6 & Reis et al $[10]$ & $1: 2$ \\
\hline
\end{tabular}

raminidase from clostridium perfringens Type VI (Sigma; St Louis, MO) diluted in $0.1 \mathrm{M} \mathrm{Na}$-acetate buffer, $\mathrm{pH} 5.5$ to a final concentration of $0.1 \mathrm{U} / \mathrm{ml}$. The incubation was carried out for $2 \mathrm{~h}$ at $37^{\circ} \mathrm{C}$ and was followed by three washings in ice-cold PBS. Sections were treated with $0.5 \%$ $\mathrm{H}_{2} \mathrm{O}_{2}$ in methanol for $30 \mathrm{~min}$, followed by $20 \mathrm{~min}$ of incubation with rabbit non-immune serum. Sections were rinsed and incubated with primary antibody (Table 1), over night at $4{ }^{\circ} \mathrm{C}$. The sections were rinsed and incubated with HRP conjucated rabbit anti-mouse secondary antibody (1:100 dilution) for $1 \mathrm{~h}$ followed by rinsing with PBS and developing with 0.05\% 3,3'-diaminobenzidine tetrahydrochloride (DAB) (SRL, Mumbai, India) freshly prepared in PBS containing $0.1 \% \mathrm{H}_{2} \mathrm{O}_{2}$. Sections were counter stained with hematoxylin, dehydrated, and mounted. All series including positive and negative controls were performed by substitution of the primary mAbs with immunoglobulins of the same class and at the same concentration.

\section{Scoring of mucins expression in H. pylori infected pre- neoplastic and neoplastic human gastric tissues}

A semi quantitative approach was used to score the immunostaining of human gastric tissues. The slides were examined under light microscope, every 100 cells were scored in five different fields and the results were expressed as mean percentage. (-), negative; + , few positive cells $(<25 \%) ;++$ well-defined areas with positive cells $(25-$ $50 \%) ;+++$, extensive areas with positive cells $(50-75 \%)$; ++++ , most cells stained $(>75 \%)$.

Table 2: Expression of mucins (MUC2, MUCSAC and MUC6) in $\mathrm{H}$. pylori infected pre-neoplastic and neoplastic human gastric epithelium

\begin{tabular}{|c|c|c|c|c|c|c|c|c|c|c|c|c|c|c|c|c|c|}
\hline \multirow[t]{2}{*}{ Stages } & \multicolumn{2}{|c|}{$\begin{array}{c}\mathrm{H} . \\
\text { pylori }\end{array}$} & \multicolumn{5}{|c|}{ MUC2 Expression } & \multicolumn{5}{|c|}{ MUC5AC Expression } & \multicolumn{5}{|c|}{ MUC6 Expression } \\
\hline & $\mathbf{N}$ & $\mathbf{P}$ & - & + & ++ & +++ & $\begin{array}{l}++ \\
++\end{array}$ & - & + & ++ & +++ & ++++ & - & + & ++ & +++ & ++++ \\
\hline $\begin{array}{l}\text { Normal } \\
(n=7)\end{array}$ & 7 & - & $\begin{array}{c}n=7 \\
(100 \%)\end{array}$ & - & - & - & - & - & - & - & $\begin{array}{c}n=2 \\
(28.6 \%)\end{array}$ & $\begin{array}{c}n=5 \\
(71.4 \%)\end{array}$ & - & - & - & $\begin{array}{c}1 \\
(14.3 \%)\end{array}$ & $\begin{array}{c}6 \\
(85.7 \%)\end{array}$ \\
\hline $\begin{array}{l}\text { Atrophic } \\
\text { gastritis } \\
(n=26)\end{array}$ & - & 26 & $\begin{array}{c}n=22 \\
(84.6 \%)\end{array}$ & $\begin{array}{c}n=4 \\
(15.4 \%)\end{array}$ & - & - & - & - & - & I (38\%) & $\begin{array}{c}13 \\
(50 \%)\end{array}$ & $\begin{array}{c}12 \\
(46.2 \%)\end{array}$ & - & - & $\begin{array}{c}1 \\
(3.8 \%)\end{array}$ & $\begin{array}{c}15 \\
(57.7 \%)\end{array}$ & $\begin{array}{c}10 \\
(38.5 \%)\end{array}$ \\
\hline $\begin{array}{l}\text { Intestinal } \\
\text { metaplas } \\
\text { ia } \\
(n=21)\end{array}$ & - & 21 & - & - & $\begin{array}{c}n=9 \\
(42.9 \%)\end{array}$ & $\begin{array}{c}\mathrm{n}=12 \\
(57.1 \%) \\
* *\end{array}$ & - & - & $\begin{array}{c}1 \\
(4.8 \%)\end{array}$ & $\begin{array}{c}16 \\
(76.2 \%) \\
* *\end{array}$ & $4(19 \%)$ & - & - & $\begin{array}{c}5 \\
(23.8 \%)\end{array}$ & $\begin{array}{c}14 \\
(66.7 \%) \\
* *\end{array}$ & $\begin{array}{c}2 \\
(9.5 \%)\end{array}$ & - \\
\hline $\begin{array}{l}\text { Dysplasia } \\
(\mathrm{n}=17)\end{array}$ & - & 17 & - & $\begin{array}{c}n=5 \\
(29.4 \%)\end{array}$ & $\begin{array}{c}n=11 \\
(64.7 \%)\end{array}$ & $\begin{array}{l}n=1 \\
(5.9 \%)\end{array}$ & - & - & $\begin{array}{c}3 \\
(17.6 \% \\
)\end{array}$ & $\begin{array}{c}10 \\
(58.8 \%)\end{array}$ & $\begin{array}{c}4 \\
(23.5 \%)\end{array}$ & - & - & $\begin{array}{c}3 \\
(17.6 \%)\end{array}$ & $\begin{array}{c}11 \\
(64.7 \%)\end{array}$ & $\begin{array}{c}3 \\
(17.3 \%)\end{array}$ & - \\
\hline $\begin{array}{l}\text { Carcino } \\
\mathrm{ma} \\
(\mathrm{n}=36)\end{array}$ & - & 36 & - & $\begin{array}{c}22 \\
(61.1 \%)\end{array}$ & $\begin{array}{c}14 \\
(38.9 \%)\end{array}$ & - & - & - & $\begin{array}{c}28 \\
(77.8 \% \\
)\end{array}$ & $\begin{array}{c}8 \\
(22.2 \%)\end{array}$ & - & - & $\begin{array}{c}12 \\
(33.3 \\
\%)\end{array}$ & $\begin{array}{c}17 \\
(47.2 \%)\end{array}$ & $\begin{array}{c}7 \\
(19.4 \%)\end{array}$ & - & - \\
\hline
\end{tabular}

$\mathrm{N}$ - negative - $(>5 \%)$ negative

$\mathrm{P}$ - positive $+(5-25 \%)$ few positive cells

$\mathrm{n}-$ No. of cases $++(25-50 \%)$ well-defined area

$+++(50-75 \%)$ extensive area stained

$++++(75-100 \%)$ most of the cells stained

$*^{* *} p<0.00, *_{p}<0.05$ (Significant difference in expression) 


\section{Statistics}

Data analysis was performed using statistical software package SPSS 10.0 for windows. The Chi-Square test or Fisher's exact test was used to analyze differences in frequencies. Spearman's correlation test was used to analyze correlation between parameters. $\mathrm{P}<0.05$ was considered statistically significant.

\section{Abbreviations}

DAB - 3,3'-diaminobenzidine tetra hydrochloride; ELISA - Enzyme-linked immunosorbent assay; HRP - Horseradish peroxidase; IARC - International Agency for Research on Cancer; IM - Intestinal metaplasia; mAbs - Monoclonal antibodies; PBS - Phosphate buffered saline; WHO - World Health Organization; RUT - Rapid Urea Test.

\section{Authors' contributions}

SDB carried out all experiments along with the designing and coordination of HD. VJ provided patients data and specimens. HD reviewed the immunohistochemical results and ND, CAR provided suggestion for the finalization of this paper. All authors read and approved the final manuscript.

\section{Acknowledgements}

The authors thank the Lady Tata Memorial Trust, Mumbai, India for the financial support to one of the authors S. Durai Babu. We grateful to Dr. Narasimhan, Professor and Head, Department of Pathology, Sri Ramachandra Medical College and Hospital, India, for reviewing the histological and immunohistochemical results and Dr. R. Ravanan, Reader, Department of Statistics, Presidemcy College, India for helping in statistical analysis. We would like to thank Dr. Celso A. Reis for provision of the anti-MUC2, antiMUC5AC and anti-MUC6 monoclonal antibodies.

\section{References}

I. Correa P: Human gastric carcinogenesis:A multistep and multifactorial process - First American Cancer Society Award Lecture on Cancer Epidemiology and Prevention. Cancer Res 1992, 52:6735-6740.

2. Parsonnet J, Friedman GD, Vandersteen DP: Helicobacter pylori infection and the risk of gastric carcinoma. N Engl] Med [99I, 325: II27-II3I.

3. Wang CC, Wu MS, Wang HH: Helicobacter pylori infection and age on the development of intestinal metaplasia - a multiple logistic regression analysis. Hepatogastroenterology 1998, 45:2234-2237.

4. International Agency for Research on Cancer. Infections with Schistosomes, Liver Flukes and Helicobacter pylori. Evaluation of Carcinogenic risks to Humans. IARC: Lyon; 1994.

5. Honda S, Fujioka T, Tokieda M, Satoh R, Nishizono A, Nasu M: Development of Helicobacter pylori - induced gastric carcinoma in Mongolian gerbils. Cancer Res 1998, 58:4255-4259.

6. Honda S, Fujioka T, Tokieda M, Gotoh T, Nishizono A, Nasu M: Gastric ulcer, atrophic gastritis, and intestinal metaplasia caused by Helicobacter pylori infection in Mongolian gerbils. Scand J Gastroenterol 1998, 33:454-460.

7. Watanabe T, Tada M, Nagai H, Sasaki S, Nako M: Helicobacter pylori infection induces gastric cancer in Mongolian gerbils. Gastroenterology 1998, I I 5:642-648.

8. Ikeno T, Ota H, Sugiyama A: Helicobacter pylori-induced chronic active gastritis, intestinal metaplasia, and gastric ulcer in Mongolian gerbils. Am J Pathol 1999, 154:951-960.
9. Futami H, Takashima M, Furuta $\mathrm{T}$, Hanai H, Kaneko : Relationship between Helicobacter pylori infection and gastric metaplasia in the duodenal bulb in the pathogenesis of duodenal ulcer. J Gastroenterol Hepatol 1999, 14: I 14-I I 9.

10. Kim YS, Gum J Jr, Brockhausen : Mucin glycoproteins in neoplasia. Glycoconj 1996, 13:693-707.

II. Gendler SH, Lancaster Ca, Taylor-Papadimitriou J, Peat T, Burchell J, Pemberton L, Lalani EN, Wilson D: Molecular cloning and expression of human tumor-associated polymorphic epithelian mycin. J Biol Chem 1990, 265:15286-15293.

12. Lan MS, Batra SK, Qi WN, Metzgar RS, Hollingsworth MA: Clonging and sequencing of a human pancreatic tumor mucin cDNA. J Blol Chem 1990, 265: I5294-15299.

13. Gum JR, BByrd JC, Hicks JW, Toribara NW, Lamport DTA, Kim YS: Molecular cloning of human intestinal mucin cDNAs. J BiolChem 1989, 264:6480-6487.

14. Gum JR, Hicks JW, Swallow DM, Laglace RL, Byrd JC, Lamport DTA, Siddiki B, Kim YS: Molecular cloning of cDNAs derived from a novel human intestinal mucin gene. Biochem Biophys Res Commun 1990, 171:407-415.

15. Dufosse J, Prochet N, Audie JP, Guyonnet-Duperat V, Laine A, Van Seuninegen I, Marrakchi S, Aubert JP: Degenerate 87-base-pair tandem repeats create hydrophilic/hydrophobic alternating domains in human mucin peptides mapped to I I I I5. Biochem J 1993, 293:329-337.

16. Guyonnet-Duperat V, Audie JP, Debailleul V, Laine A, Buisine MP, Galieque-Zouitina S, Pigny P, Degand P, Aubert JP, Porchet N: Characterization of the human mucin gene MUC5AC : a consensus cysteine-rich domain for II PI5 mycin genes? Biochem J 1995, 305:21I-219.

17. Porchet N, Van-Cong N, Dugosse J, Audie JP, Guyonne-Duperat V, Gross MS, Denis C, Degand P, Bernhein A, Aubert JP: Molecular cloning and chromosomal localization of a novel human tracheo-bronchial mucin cDNA containing tandemly repeated sequences of 48 base pairs. Biochem Res Commun 1991, 175:4|4-422.

18. Bobek LA, Tsai H, Biesbrock AR, Levine MJ: Molecualr cloning sequence and specificity of expression of the gene encoding the lower molecular weight human salivary mucin (MUC7). J Biol Chem 1993, 268:20563-20569.

19. Toribara NW, Roberton AM, Ho SB, Kyo WL, Gum E, Hicks JW, Gum JR, Byrd JC, Siddiki B: Human gastric mucin. Identification of a unique species by expression cloning. J Biol Chen 1993, 268:5879-5885.

20. Shankar V, Gilmore MS, Elkins RC, Sachdev GP: A novel human airway mucin cDNA encodes a protein with unique tandemrepeat organization. Biochem J 1994, 300:295-298.

21. Audie JP, Janin A, Porchet N, Copin MC, Gosselin B, Aubert JP: Expression of human mucin genes in respiratory, digestive and reproductive tracts ascertained by in situ hybridization. J Histochem Cytochem 1993, 41: I479- I485.

22. DeBolós C, Garrido M, Real FX: MUC6 apomucin shows a distinct normal tissue distribution that correlates with Lewis antigen expression in the human stomach. Gastroenterology 1995, 109:723-734.

23. Ho SB, Shekels LL, Toribara NW, Kim YS, Lyftogt C, Cherwitz DL, Niehans GA: Mucin gene expression in normal, pre-neoplastic, and neoplastic human gastric epithelium. Cancer Res 1995, 55:268I-2690.

24. Nielsen PA, Mandel U, Therkildsen MH, Clausen H: Differential expression of human high molecular weight salivary mucin (MGI) and low molecular weight salivary mucin (MG2). J Dent Res 1996, 75: 1820-1826.

25. Carrato C, Balague C, DeBolos C, Gonzalez E, Gambus G, Planas I, Perini JM, Andreu D, Real FX: Differential apomucin expression in normal and neoplastic human gastrointestinal tissues. Gastroenterology 1994, 107:160-172.

26. Reis CA, David L, Nielsen P: Immunohistochemical study of MUC5AC expression in human gastric carcinomas using a novel monoclonal antibody. Int J Cancer 1997, 74: II2-I2I.

27. Ho SN, Niehans GA, Lyftoget C, Yan PS, Cherwitz DL, Gum ET, Dahiya R, Kim YS: Heterogeneity of mucin gene expression in normal and neoplastic tissues. Cancer Res 1993, 53:64-65I.

28. Buisine MP, Janin A, Maunoury V, Audie JP, Delesaut MP, Copin MC, Colombel JF, Degand P, Aubert JP, Porchet N: Aberrant expres- 
sion of a human mucin gene (MUC5AC) in rectosigmoid vilous adenoma. Gastroenterology 1996, 104:93-102.

29. Corfield A, Myerscough N, Gough M, Brockhausen I, Schauer R, Paraskeva C: Glycosylation patterns of mucins in colonic disease. Biochem Soc Trans 1995, 23:840-845.

30. Gambús G, de Bolós C, Andreu D, Francí C, Egea G, Real FX: Detection of the MUC2 apomucin tandem repeat with a mouse monoclonal antibody. Gastroenterology 1993, 104:93-102.

31. Byrd JC, Yan P, Sternberg L, Yunker CK, Scheiman JM, Bresailer RS: Aberrant expression of gland-type gastric mucin in the surface epithelium of Helicobacter pylori-infected patients. Gasteroenterology 1997, I | 3:455-464.

32. Reis CA, David L, Seixas M, Burchell J, Sobrinho-Sinoes M: Expression of fully andused glycosylated ofrms of MUCI mucin in gastric carcinoma. Int J Cancer 1998, 79:402-4I0.

33. Brink GR, Tytgat Kmal, Hulst LWM: $\boldsymbol{H}$. pylori colonolizes with MUC5AC in the human stomach. Gut 2000, 46:60I-607.

34. Belma Kover MD, Murat Vlas MD, Yucel Ustundag MI, Sibel Erodogan MD, Melih Karabeyoglu MD, Osman Yildin MD, Bulent oral MD, Omer Lengiz MD, Atilla Soran MO: A confirmatory report for the close interaction of Helicobacter pylori with gastric epithelial MUC5AC expression. J Clin Gastroentrol 2004, 38:486-502.

35. Hakomori S: Aberrant glycosylation in tumours and tumorassociated carbohydrate antigens. Adv Cancer Res 1989, 52:257-331.

36. Springer GF, Desai PR, Ghazizadeh M, Tegtmeyer H: T/Tn pancarcinoma autoantigens: fundamental, diagnostic and prognostic aspects. Cancer Detect Prev 1995, 19:173-183.

37. Girling A, Bartkova J, Gendler S, Gillett C, Taylor-Papadimitriou J: A core protein epitope of the polymorphic epithelial mucin detected by the monoclonal antibody SM-3 is selectively exposed in a range of primary carcinomas. Int J Cancer 1989, 43:1072-1076

38. Melro GR, Siddiqui J, Cropp CS, Liscia DS, Lidereau R, Callahan R, Kufe DW: Frequent alteration of the DF3 tumour-associated antigen gene in primary human breast carcinomas. Cancer Res 1989, 49:6966-697I.

39. Burchell J, Gendler S, Taylor-Papadimitriou J, Girling A, Lewis A, Millis $\mathrm{R}$, Lamport D: Development and characterization of breast cancer reactive monoclonal antibodies directed to the core protein of the human milk mucin. Cancer Res 1987, 47:5476-5482.

40. Reis CA, Sorensen T, Mandel U: Development and characterization of an antibody directed to an $\alpha-\mathrm{N}$-acetyl-D-galactosamine glycosylated MUC2 peptide. Glycoconj J 1998, 15:5I-62.

41. Correa PA: Human model of gastric carcinogenesis. Cancer Res 1988, 48:3554-3560

42. Filipe MI, Jass JR: Intestinal metaplasia subtypes and cancer risk. Edited by: Filipe MI, Jass JR. Gastric Carcinoma, London: Churchill Livingstone; 1986:87-II5.

43. Naomi Uemura, Shiro Okamoto, Sorchiro Yamamoto : Helicobacter pylori infection and the development of Gastric Cancer. NEngl I Med 200I, 345:32-4I.

44. Dixon MF, Genta RM, Yardley H, Lorea P: Classification and grading of gastritis : the updated sydney system. International workshop on the histopathology of gastritics, Houton 1994. Am J surg Pathol 1996, 20:1161-II81.

45. Lauren P: The two main histological types of gastric carcinoma: diffuse and so-called intestinal type carcinoma. An attempt at a histo-clinical classification. Acta Pathol Microbiol Scand 1965, 64:31-49.

46. Watanabe $\mathrm{H}$, Jass JR, Sobin LH: Histological typing of esophageal and gastric tumors. In WHO International Histological Classification of Tumours 2nd edition. Springer, Berlin; 1990.

47. Reis CA, David L, Carvalho F: Immunohistochemical study of the expression of MUC6 mucin and coexpression of other secreted mucins (MUC5AC and MUC2) in human gastric carcinomas. J Histochem Cytochem 2000, 48:377-388.

48. Reis CA, David L, Correa P, Carneiro F, de Bolos C, Garcia E, Mandel $\mathrm{U}$, Clausen $\mathrm{H}$, Sobrinho-Simoes M: Intestinal metaplasia of human stomach displays distinct patterns of mucin (MUCI, MUC2, MUC5AC, and MUC6) expression. Cancer Res 1999, 59:1003-1007. 